\title{
Fever and antipyretic therapy in the septic patient in the intensive care unit: an update
}

\author{
Alejandro Donoso* and Daniela Arriagada \\ Unidad de Paciente Crítico Pediátrico, Hospital Clínico Metropolitano La Florida, Santiago, Chile
}

\begin{abstract}
Fever is a very common sign to observe in critically ill children during their Intensive Care Unit stay, which should be understood as an evolutionary biological response of normal adaptive character from the host to physiological stress. It is the result of a complex response to pyrogenic stimuli, resulting in the generation of cytokines and prostaglandins. The molecular mechanisms involved in the onset of fever are not yet fully specified. Therefore, difficulties in the knowledge of the exact pathophysiological processes involved are created, so it is necessary to elaborate an adequate and specific therapeutic strategy. Experimental studies conclude that fever and inflammation are beneficial to the host. However, antipyretic therapy is commonly employed, and human studies on the presence of fever and its treatment for the prognosis of critically ill septic patients are inconclusive. Up-to-date information on the physiology of human thermoregulation, the effect of temperature on the febrile range over multiple biological processes involved in host defense, and thermoregulatory interventions in the septic patient are essential to know by the critical care physician.
\end{abstract}

Key words: Temperature. Fever. Cytokines. Antipyretics. Sepsis. Intensive care.

\section{Fiebre y terapia antipirética en el paciente con sepsis en la unidad de cuidados intensivos: actualización}

\section{Resumen}

La fiebre es un signo frecuente en el niño críticamente enfermo durante su estadía en la unidad de cuidados intensivos, y debe ser entendida como una respuesta biológica evolutiva, de carácter adaptativo normal del huésped al estrés fisiológico. Es el resultado de una compleja respuesta a estímulos pirogénicos, resultando en la generación de citocinas y prostaglandinas. Los mecanismos moleculares implicados en el inicio de la fiebre aún no están totalmente precisados, originando dificultades en el conocimiento de los procesos fisiopatológicos exactos involucrados y, por ende, necesarios para elaborar una adecuada y específica estrategia terapéutica. Estudios experimentales concluyen que la fiebre y la inflamación son benéficas para el huésped; no obstante, la terapia antipirética es comúnmente empleada y estudios en humanos sobre la presencia de fiebre y su tratamiento para el pronóstico del paciente crítico con sepsis no son concluyentes. Para el médico intensivista es esencial disponer de información actualizada referente a la fisiología de la termorregulación humana, el efecto de la temperatura en rango febril sobre múltiples procesos biológicos involucrados en la defensa del huésped y las intervenciones termorreguladoras en el paciente con sepsis.

Palabras clave: Temperatura. Fiebre. Citocinas. Antipiréticos. Sepsis. Cuidados intensivos.

\section{Correspondencia:}

${ }^{\star}$ Alejandro Donoso

E-mail: adonosofuentes@gmail.com
Available online: $23-11-2018$

Bol Med Hosp Infant Mex. 2018;75:171-183

www.bmhim.com

2444-3409/@ 2018. Hospital Infantil de México Federico Gómez, published by Permanyer México SA de CV, all rights reserved. 


\section{Introduction}

"Humanity has three great enemies: fever, famine, and war; of these by far the greatest, by far the most terrible, is fever." (William Osler)

Although the temperature is a primary vital sign, its assessment in the critical patient has received little attention compared to other signs since infectious diseases, unlike those signs, occasionally affect the thermoregulatory system.

In the Intensive Care Unit (ICU), fever frequently occurs in both adults ${ }^{1}$ and the pediatric ${ }^{2}$ patients, although its origin can be diverse, sepsis is its leading cause, reaching $74 \%$ in hospitalized patients ${ }^{3}$, while in the pediatric population infectious pathologies represent $80 \%{ }^{4}$. Fever should be regarded as an essential component of the host systemic inflammatory response, being an important defense and resistance mechanism against infections, by which the organism itself undergoes temporal thermal stress as a global regulatory mechanism ${ }^{5}$.

There is important experimental evidence in animals regarding the benefit of fever ${ }^{6,7}$; however, its presence has a deleterious effect in patients with acute brain damage, neuropsychiatric alteration and in patients with limited cardiorespiratory reserve (shock) or those who present metabolic instability ${ }^{8}$.

There are misconceptions about fever and its treatment both in the general population as well as in the medical one ${ }^{9-14}$. Usually, fever is treated in many ICUs broadly and systematically, and it is common for the patient to receive non-pharmacological and pharmacological therapy since a putative risk to health is attributed to this condition; however, there is no conclusive evidence in favor of its routine treatment ${ }^{15}$.

It should be kept in mind that the fever treatment will always intervene with the inflammatory process that undergoes in the host ${ }^{5}$. On the other hand, pharmacological agents to reduce fever can cause undesirable hemodynamic effects (arterial hypotension) ${ }^{16}$, platelet dysfunction and gastrointestinal bleeding ${ }^{17}$ or hepatorenal dysfunction in the dehydrated patient or the one with associated morbidities ${ }^{18-24}$.

Finally, for various specific conditions, it is not yet defined if fever or the physiological response to it causes morbidity and mortality and whether its treatment confers any benefit. In the septic patient, the thermal control, as well as its purpose, remain under debate ${ }^{8,25,26}$.

The objective of this review is to provide an update on the thermoregulatory mechanisms and fever development from an evolutionary perspective, in its physiopathology and the available evidence of its beneficial and harmful effects. Specifically, the role of fever and the use of antipyretic therapy on infections in the critically ill patient are analyzed. There was no systematic review of the subject.

\section{Body temperature regulation}

Endothermy is a characteristic of all mammals and birds ${ }^{27,28}$, which regulates body temperature through the balance between heat generation and heat loss. The heat is produced by the metabolic activity and depending on the environmental temperature it can be acquired from or lost to the environment. In response to infection, many animals temporarily increase their temperature between $2^{\circ} \mathrm{C}$ and $4^{\circ} \mathrm{C}$ by altering the balance between heat generation and heat loss ${ }^{29}$.

In mammals, homeostatic control of body temperature (thermoregulation) is essential and is strictly regulated $\left( \pm 0.2^{\circ} \mathrm{C}\right)$, it is obtained through autonomic, endocrinological, metabolic, and behavioral mechanisms ${ }^{30,31}$. Unlike other mammals, humans have a high protective capacity against heat, produced through autonomic thermoregulation of cutaneous blood flow and transpiration.

The thermoregulation system comprises a network of peripheral and central location thermoreceptors (sensory afferent pathway), a control center (hypothalamus) and effector mechanisms of body heating and cooling, which include the regulation of peripheral blood flow, shivers production, and sweating (evaporative cooling) (Fig. 1).

It should be noted that the autonomic thermoregulatory activity is similar in children and adults under neutral environmental conditions; however, there are some unique patterns in infants ${ }^{32}$ and children, who present a lower adaptation to extreme environmental temperatures (higher body surface/mass ratio and less evaporative loss) ${ }^{33}$ as well as in pre-pubertal adolescents ${ }^{34}$. The neonatal patient presents thermoregulatory instability during the first 2-3 days of life, then achieving an adequate homeothermia ${ }^{35}$.

The accepted normal range for body temperature is from $36.1^{\circ} \mathrm{C}$ to $37.8^{\circ} \mathrm{C}^{36}$, presenting variations with physical activity and environmental factors ${ }^{37}$. The central temperature is higher in the pediatric patient than in the adult $^{38}$.

In addition to the strict control of temperature, there is a rhythmic variability in periods of $24 \mathrm{~h}$, which is associated with the sleep-wake cycle (morning nadir) ${ }^{39}$. This circadian rhythm is altered in the critically ill patient ${ }^{40}$. 


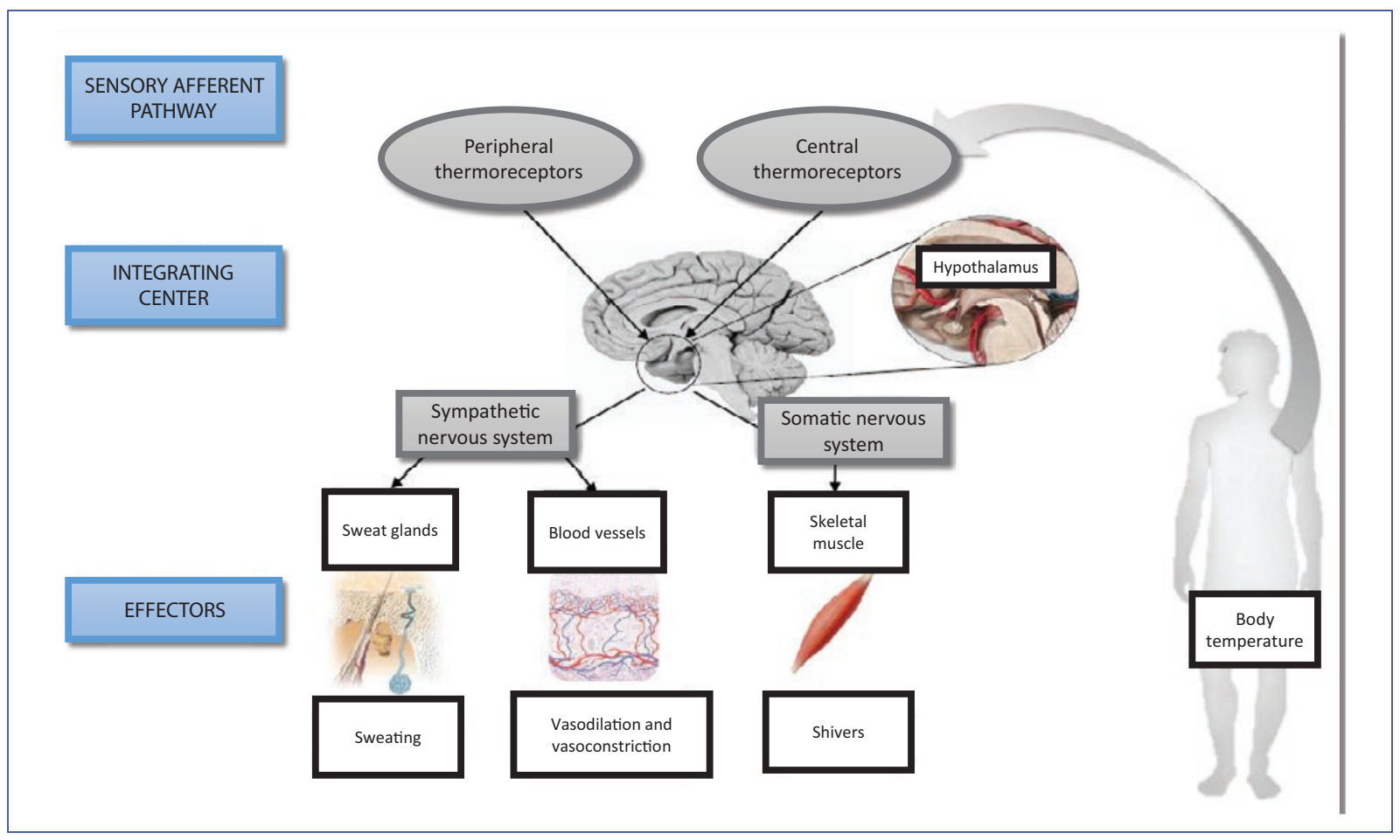

Figure 1. Human thermoregulatory system: the thermoregulation system comprises a network of peripheral and central thermoreceptors (sensory afferent pathway), an integrating center (hypothalamus) and effector mechanisms of body heating and cooling, which include regulation of peripheral blood flow, shiver production, and sweating (evaporative cooling).

\section{Definition of fever, febrile response, and hyperthermia}

The definition of fever is arbitrary since it depends on the method used for its measurement ${ }^{41}$, the studied population (infection and post-resuscitation care) and the purpose for which it is determined ${ }^{42}$.

Fever is understood as the regulated elevation of the central temperature as a consequence of a complex inflammatory process, which originates in the thermoregulatory center. Fever is often, but not necessarily, part of the host's defensive response to infectious and non-infectious stimuli recognized as pathogenic or strange ${ }^{43}$. As a result, rapid and stereotyped response of the innate immune system ${ }^{44}$ to infections occurs, where the body temperature rarely exceeds $41^{\circ} \mathrm{C}$ and does not cause tissue damage.

It should be noted that fever is one of the components of the febrile response, which is understood as a physiological reaction mediated by cytokines and characterized by the elevation of the thermostatic set point, involving the generation of acute phase reactants, and activation of central nervous, autonomic, immune and endocrine systems, in addition to a component of behavioral change ${ }^{30,45-47}$.

Finally, fever should be distinguished from hyperthermia $\left(>41^{\circ} \mathrm{C}\right)$, which corresponds to an increase in body temperature not caused by a shift in the hypothalamic thermostatic set point that does not have diurnal variation, which is potentially harmful and where pyrogenic cytokines are not involved directly. Hyperthermia is due to an alteration in the mechanisms that control the production and loss of heat (excessive environmental temperature, neuroleptic malignant syndrome, and severe thyrotoxicosis).

According to the World Health Organization, fever is defined as $\mathrm{a} \geq 37.5^{\circ} \mathrm{C}$ rectal temperature ${ }^{37}$ in children. Clinically, fever is the appearance of a $1^{\circ} \mathrm{C}$ or higher increase in the body temperature compared to the average temperature of the place where it is evaluated. The levels accepted as fever are $\geq 38^{\circ} \mathrm{C}$ for rectal and $\geq 37.4^{\circ} \mathrm{C}$ for axillary temperature ${ }^{48}$. The importance of the increase of at least $1^{\circ} \mathrm{C}$ more than the average 


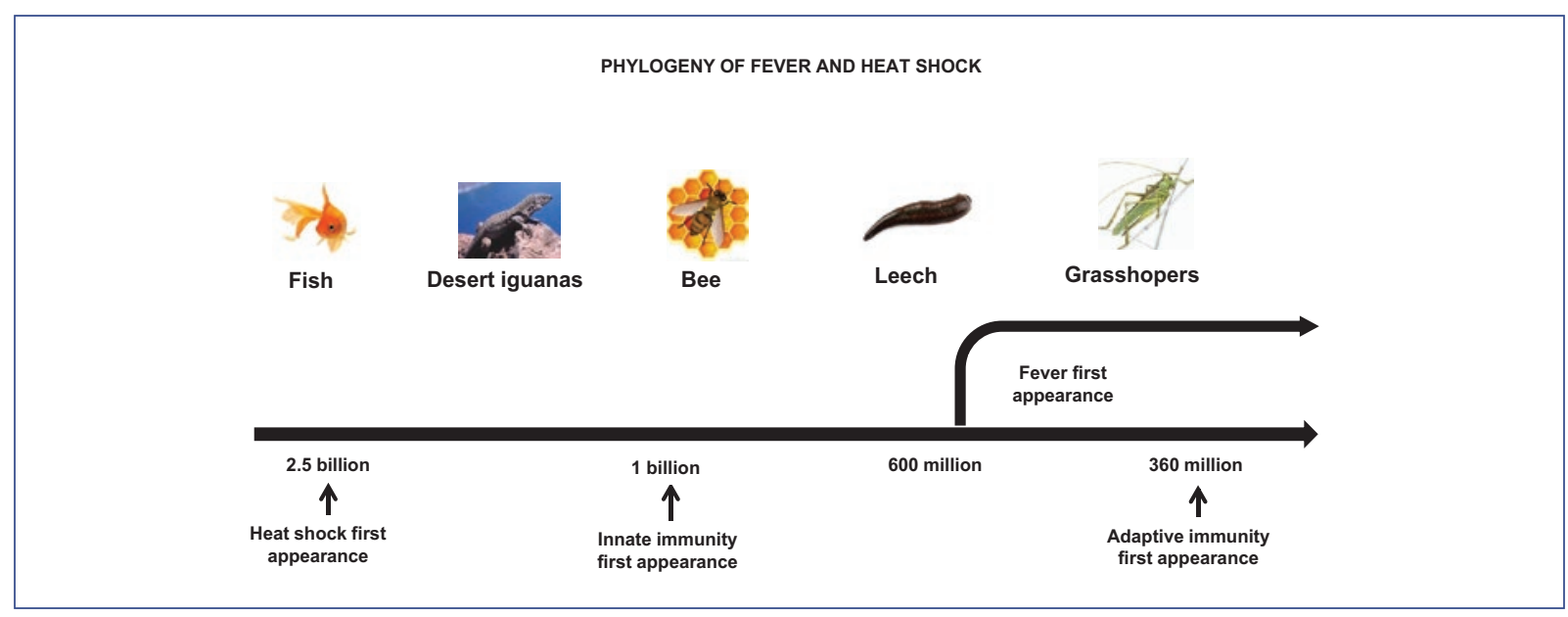

Figure 2. The phylogenetic relationships between fever, heat shock, innate, and adaptive immunity. Animals today use fever as a strategy to cope with an infection. The approximate phylogenetic origin of fever (600 million years) and the related biological processes are also shown.

temperature lies in the diurnal variation of the normal body temperature, which is higher in the afternoon (17$19 \mathrm{~h}$ ). These fluctuations are greater in children than in adults and more pronounced during febrile episodes ${ }^{48}$.

\section{Fever mechanisms: an evolutionary strategy}

From an evolutionary perspective, fever has risen as an additional host response to infection, before the onset of adaptive immunity, but in the setting of already well-established heat shock and innate immunity responses in major animals. Thus, fever is a primitive and phylogenetically preserved immune response in mammals and birds ${ }^{49}$, dating back probably to 600 million years ago ${ }^{5,50}$ (Fig. 2). This response is generally considered limited to homeothermic animals; however, many poikilothermic animals such as minor vertebrates $^{51}$, arthropods ${ }^{52}$, and annelids develop a similar process, increasing their core temperature in the presence of infection by seeking a warmer environment.

Fever has been documented in the two main divisions of animals: deuterostomes and protostomes, suggesting that the increase in core temperature in response to infection is a conserved survival strategy, which evolved from the separation moment of both evolutionary lines ${ }^{5}$. On the other hand, fever can be blocked by inhibition of the enzyme cyclooxygenase (COX) in various species of poikilotherms ${ }^{53,54}$ and homeotherms, which suggests the possibility that the fever development mechanisms may have evolved from a common ancestor.
Although the normal body temperature of a mammal is determined by the climatic temperature when it first appeared on our planet ${ }^{55}$, a recent study calculated that the optimal central temperature of a mammal is approximately $36.7^{\circ} \mathrm{C}$, derived from the compensation between bacterial spread by hypothermia and the metabolic cost increase of hyperthermia ${ }^{56}$.

\section{Molecular and cellular bases}

Fever development requires that various communication pathways between the nervous and immune systems propagate the inflammatory response to the central nervous system immediately after the peripheral activation of the innate immune system ${ }^{57}$ (Fig. 3).

In the classical model of infection-induced fever, the exogenous pyrogen lipopolysaccharide (LPS) ${ }^{44}$, a prototype of a pathogen-associated molecular pattern (PAMP), is identified by the pattern recognition receptors or Toll-like receptor-4 in what we can call a "first wave" 58 . These receptors are located in circulating peripheral immune cells (monocytes and macrophages) and resident cells (hepatic Kupffer cells), causing genetic transcription, synthesizing and releasing endogenous pyrogens such as interleukin (IL)-1, tumor necrosis factor-alpha (TNF- $\alpha)^{59}$ and others such as IL-6 and interferon $\gamma$ (Table 1). These cytokines, together with the PAMPs, will trigger a "second wave" of activation, which originates a communication between immune and nervous systems through vagal receptors (brainstem nucleus of the solitary tract), in the blood-brain barrier (BBB) and in the circumventricular organs, 


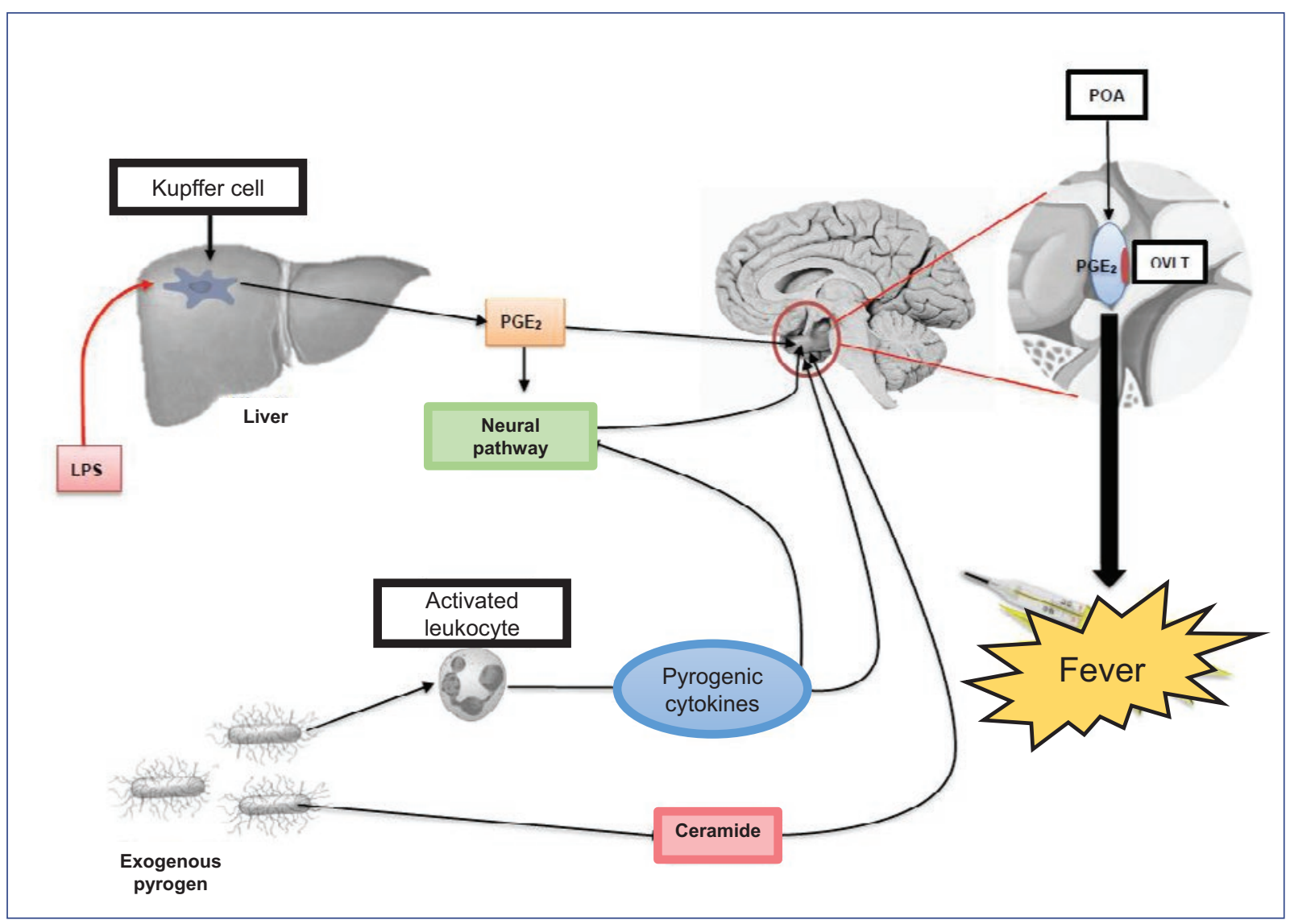

Figure 3. Proposed mechanism of the generation of fever in sepsis. The stimulation of sentinel cells by exogenous pyrogens produces endogenous pyrogens, which stimulate the fever production in the hypothalamic preoptic area (POA), through second messengers such as PGE2 and ceramide. PGE2 is also produced in Kupffer cells, in the liver, in response to the stimulation of LPS, which additionally stimulates the POA through the vagus nerve. OVLT: organum vasculosum of the lamina terminalis; LPS: lipopolysaccharide; PGE2: prostaglandin E2. (Modified from Walter et al. ${ }^{157}$ ).

specifically the Organum Vasculosum of the Lamina Terminalis (OVLT). The OVLT is located in the optic recess of the anteroventral region of the third ventricle and connects with the preoptic hypothalamic nuclei ${ }^{44,60,61}$.

It should be noted that the exact mechanism by which circulating cytokines (hydrophilic molecules) reach the neural tissue has not been fully elucidated. Several hypotheses have been proposed, such as a BBB alteration in the OVLT area, active transport of cytokines, or activation of cytokine receptors in the endothelium of the neural vasculature ${ }^{62}$.

OVLT synthesizes intracerebral prostaglandin E2 (PGE2), which is the terminal critical mediator ${ }^{63}$, through inducible COX-2 enzyme and microsomal prostaglandin E1 synthase ${ }^{64,65}$. In experimental animal models, it has been demonstrated that the COX-2 transcription mechanism exhibits upregulation at the endothelial level and in perivascular cells of the cerebral microvasculature between 90 min and $12 \mathrm{~h}$ after the LPS administration ${ }^{65-68}$. Through the cyclic AMP, intracerebral PGE2 acts in the preoptic nucleus reducing the firing frequency of heat-sensitive neurons, causing a response that has the aim of decreasing heat loss and increasing its production until the body reaches a new hypothalamic temperature set-point, which once achieved, will be sustained by the same mechanism used in the regulation of normal body temperature.

PGE2 is actively removed from the brain by the organic anion transporter-3, but the relationship between its brain clearance rate and the fever duration has not yet been established ${ }^{69}$.

The lipid derivative ceramide can act as a second messenger independently of PGE2, being of particular importance in the early stages of the fever generation ${ }^{70}$. 
Table 1. Main endogenous pyrogens, antipyretic mediators and their action.

\begin{tabular}{|c|c|}
\hline Mediator & Role in fever \\
\hline IL-1 & $\begin{array}{l}\text { The most potent endogenous pyrogen in } \\
\text { humans }\end{array}$ \\
\hline TNF- $\alpha$ & $\begin{array}{l}\text { Endogenous pyrogen. Inflammatory } \\
\text { mediator }\end{array}$ \\
\hline IL-6 & Endogenous pyrogen \\
\hline IL-8 & Endogenous pyrogen \\
\hline IFN- $\gamma$ & Endogenous pyrogen \\
\hline MIP-1 $\beta$ or CCL4 & $\begin{array}{l}\text { Chemokine of monocytes and } \mathrm{T} \\
\text { lymphocytes, among other immune cells }\end{array}$ \\
\hline$N F-\kappa B$ & $\begin{array}{l}\text { Transcriptional factor that controls } \\
\text { endogenous pyrogens expression }\end{array}$ \\
\hline AP-1 & $\begin{array}{l}\text { Transcriptional factor that controls } \\
\text { endogenous pyrogens expression }\end{array}$ \\
\hline IL-1 RA & Endogenous antipyretic cytokine \\
\hline IL-10 & Endogenous antipyretic cytokine \\
\hline TNF- $\alpha-B P$ & Endogenous antipyretic cytokine \\
\hline AVP & Endogenous antipyretic \\
\hline$\alpha-M S H$ & Endogenous antipyretic \\
\hline Glucocorticoids & Endogenous antipyretic \\
\hline ACTH & Endogenous antipyretic \\
\hline
\end{tabular}

IL-1: interleukin-1; TNF- $\alpha$ : tumor necrosis factor alpha; IL-6: interleukin-6; IL-8: interleukin-8; IFN- $\gamma$ : interferon gamma; MIP-1 $\beta$ : macrophage inflammatory protein-18; CCL4: C-C motif chemokine 4; NF-KB: nuclear factor-kappa b; AP-1: activator protein-1; IL-1 RA: IL-1 receptor antagonist; IL-10: interleukin-10; TNF- $\alpha$-BP: tumor necrosis factor binding protein; AVP: arginine-vasopressin; $\alpha$-MSH: alpha-melanocyte-stimulating hormone; ACTH: adrenocorticotropic hormone.

It should be highlighted the existence of a negative feedback mechanism mediated by glucocorticoids, through nuclear factor-kappa B and activator protein-1. Moreover, the febrile response is also regulated by specific antipyretic cytokines (Table 1).

There is evidence in numerous experimental models of the COX-2 participation in the neural vasculature for the fever generation ${ }^{71}$. Thus, COX-2 knockout mice are not capable of producing a febrile response $^{72}$, and in humans, the use of selective COX2 inhibitors reduce fever ${ }^{73,74}$. However, pyrogenic cytokines stimulate PGE2 production and can also contribute to the fever development through alternative pathways (PGE2-independent) ${ }^{75}$, which could explain the therapeutic failure of COX-2 inhibitors in some patients.

\section{Metabolic consequences of fever}

The stimulation of the hypothalamic preoptic area by pyrogenic mediators in the septic patient causes a sympathetic activation ${ }^{76}$ inducing tachycardia (adrenergic stress $)^{77}$. However, this can also occur in the presence of sympathetic activity blockade ${ }^{78}$. Hence, a role of humoral mediators (prostanoids) and metabolic factors on cellular receptors of the cardiac pacemaker is attributed ${ }^{79}$.

The body temperature increase causes an increment in heart rate (10 beats/min for each degree Celsius) ${ }^{80,81}$, cardiac output and oxygen consumption $\left(\mathrm{VO}_{2}\right)^{82}$, in addition to the enhanced production of carbon dioxide $\left(\mathrm{VCO}_{2}\right)^{83}$ and catecholamines ${ }^{84}$.

Conversely, body cooling in the sedated and ventilated febrile patient reduces energy expenditure ${ }^{85}$, and in the critically ill patient it reduces $\mathrm{VO}_{2}$ by $10 \%$ for each degree Celsius decreased in the core temperature as well as $\mathrm{VCO}_{2}^{3,86}$. From the above, it seems evident that any beneficial effect of fever should always be evaluated individually and according to the metabolic cost caused by it, especially in patients with low cardiorespiratory reserve (high doses of inotropes and vasopressor agents and patient-ventilator asynchrony).

\section{Immunological consequences of fever}

Fever induces the production of heat shock proteins (HSPs), which are highly preserved between different organisms ${ }^{87}$ and are expressed in response to various stimuli or stress conditions ${ }^{88,89}$, these proteins are essential for cell survival ${ }^{90}$; their function is to provide thermotolerance to the cell $29,91-93$.

In the presence of fever, the neutrophils transendothelial extravasation ${ }^{94}$ and the phagocytosis capability are optimized ${ }^{95}$. Moreover, the L-selectin-mediated binding of the human lymphocyte to the vascular endothelium is improved with the temperature in a febrile range, which favors the lymphocyte migration to the site of tissue inflammation. However, neutrophils and macrophages present a significant decrease in their functioning at temperatures of $41^{\circ} \mathrm{C}^{96}$. Finally, the increase in temperature causes acceleration of caspase-dependent apoptosis in human neutrophils, a process that plays a role in limiting inflammation and tissue damage during infection ${ }^{97}$.

\section{Pharmacological consequences of fever}

Fever can affect the absorption, distribution, and elimination of some drugs used in critical patients. Few 


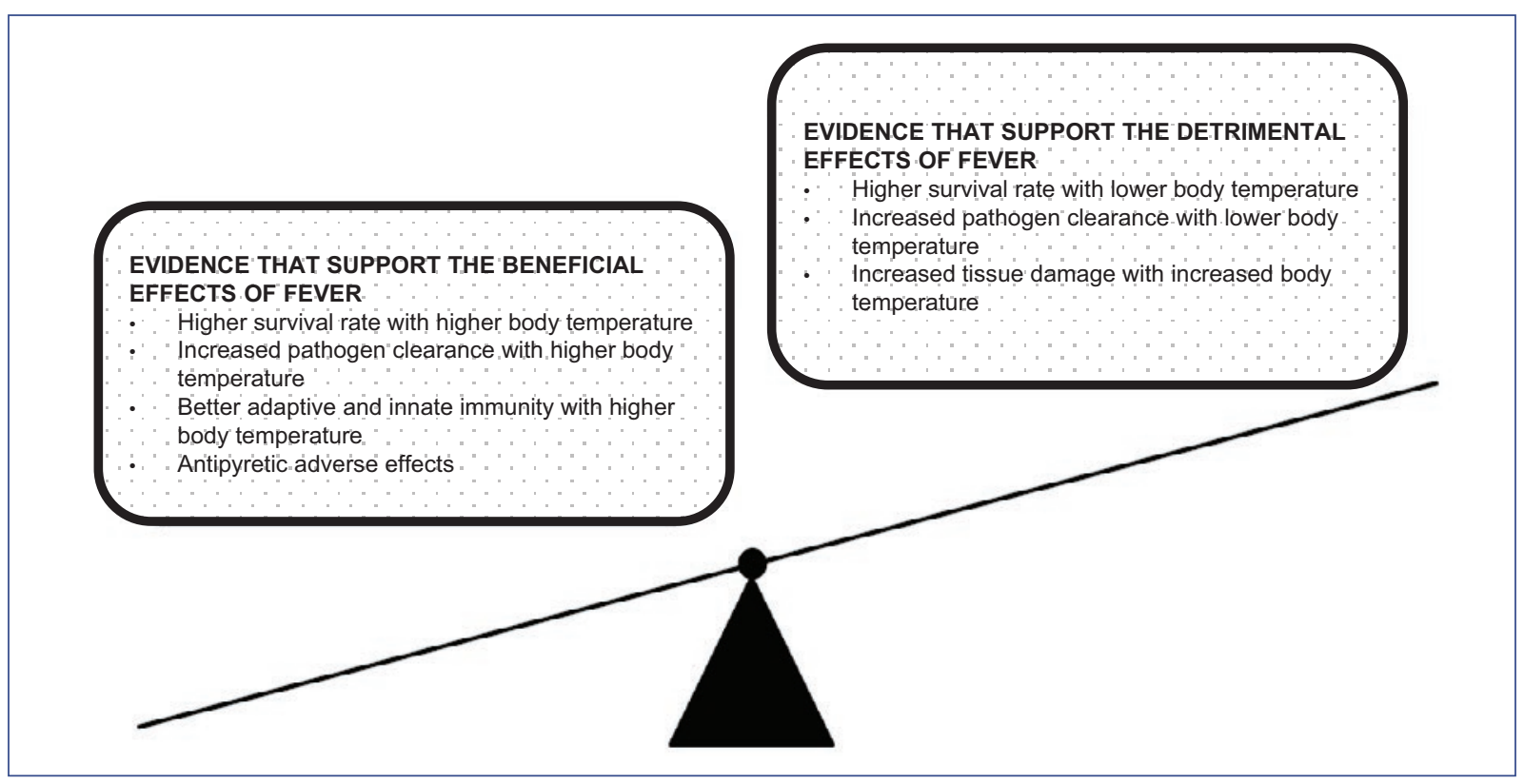

Figure 4. The balance of the evidence from the experimental studies that support the beneficial effects versus the detrimental effects of fever.

studies have been conducted in humans ${ }^{98}$, and alteration in the pharmacokinetic profile has been described for some antibiotics ${ }^{99}$. Thus, there is still no certainty about the effects of fever on the drug's pharmacokinetics and pharmacodynamics that eventually allow pharmacological therapy to be modified in febrile septic patients.

\section{Importance of fever in animals with infection}

A subject of debate for many decades has been whether the development of fever represents a beneficial or risky response to the host, ${ }^{100}$ and there is still no unappealable answer available. Perhaps the most powerful argument to support its beneficial effect has teleological bases ${ }^{7,50}$. As noted above, fever is present in ectothermic vertebrate animals (reptiles, amphibians, and fish) and endotherms (mammals and birds), as well as in some invertebrates. Given the significant metabolic-energetic and nutritional cost of the febrile respon$\mathrm{se}^{83}$, its persistence in such a large group of organisms gives us evidence of its evolutionary advantage ${ }^{7}$, which has been demonstrated by various experimental animal models. For example, the pioneering studies of Kluger et al. ${ }^{100}$ concerning the heat-seeking behavior in infected lizards and their effect on survival are important ${ }^{7,53,101}$.
The artificial temperature increase has proven to increment the mice survival to infection produced by herpes simplex virus ${ }^{102}$, poliovirus ${ }^{103}$, coxsackievirus ${ }^{104}$, rabies virus ${ }^{105}$, and in an experimental model of bacterial peritonitis due to Klebsiella pneumoniae ${ }^{106}$. However, it should be noted that this thermal increase is not homologous to the febrile response in endothermic animals.

In an animal model of septic shock, longer survival was demonstrated in the experimental group (fever $>39^{\circ} \mathrm{C}$ ), while the use of antipyretic therapy was associated with lower HSP70 circulating levels ${ }^{107}$.

Moreover, a meta-analysis on the effect of the use of antipyretic drugs in animals infected with influenza virus showed that its use was associated with a higher risk of mortality ${ }^{108}$. Similar findings have been demonstrated for bacterial infections ${ }^{53,109,110}$.

Although considerations derived from an evolutionary point of view support the protective effect of fever, these are not necessarily applicable to the critical patient at present, in whom the elimination of pathogens is pharmacologically supported.

In summary, although there is no uniform answer from experimental studies on the benefit of fever in critical illness, the balance subtly leans toward its beneficial value (Fig. 4). However, the protective effects of these experimental findings have not yet been manifested in the clinical context. 
Table 2. Proposed criteria for the selection between pharmacological and non-pharmacological antipyretic therapy for the septic patient.

\begin{tabular}{|l|l|}
\hline Antipyretic drug & External cooling \\
\hline Not sedated patient & Hypothalamic dysfunction \\
\hline $\begin{array}{l}\text { Simultaneous need of } \\
\text { analgesia }\end{array}$ & Need for strict thermal control \\
\hline $\begin{array}{l}\text { Patient with hemodynamic } \\
\text { instability }\end{array}$ \\
\hline $\begin{array}{l}\text { No response to pharmacological } \\
\text { therapy }\end{array}$ \\
\hline
\end{tabular}

\section{Fever in the patient with infection}

Taking into consideration the previously described data (vide supra) the question should be the following. Under what conditions is it beneficial to treat a fever?

The effect of fever on the prognosis of the adult patient remains controversial, at least in part, because it has been reported the use of various definitions and different moments of fever assessment, making it difficult to identify a threshold for the development of relevant clinical consequences. Several studies in septic patients have reported a deleterious ${ }^{111}$, neutral ${ }^{112}$, or beneficial ${ }^{113}$ effect of fever. Recently, a large retrospective cohort study showed in non-neutropenic septic patients that the presence of fever is associated with lower mortality, a finding not evidenced in neutropenic patients, which could suggest a relationship between neutrophil activation during the febrile episode and mortality ${ }^{114}$.

In the pediatric population, few reports investigate the role of fever in the ICU patient. Gordijn et al. ${ }^{2}$ pointed out in a retrospective observational study that $40 \%$ of the patients presented fever during their stay in the ICU, the majority within the first $48 \mathrm{~h}$ of admission and concerning the primary diagnosis. The fever that began after $48 \mathrm{~h}$ was associated with a longer stay.

The scientific literature indicates an increased risk related to the development of fever and reveals a relation between the fever magnitude $\left(>39.5^{\circ} \mathrm{C}\right)$, the severity of the disease and mortality. Therefore, it seems reasonable to assume that antipyretic treatment could improve the patient's prognosis; however, as noted below, this presumption is not as evident as it seems.

\section{Antipyretic therapy to the patient with infection}

Various approaches to fever control have been proposed:

- Treatment: a drug is administered when the temperature exceeds a predefined threshold

- Strict prevention of fever: temperature is maintained below the fever threshold

- Strict maintenance of normothermia: through targeted temperature management (TTM), where a predefined range of normothermia $\left(36-37^{\circ} \mathrm{C}\right)$ is held.

Regarding the therapeutic strategies used in the febrile patient, there is no standardized practice, although its use is usually justified in terms of well-being assurance and reduction of cardiorespiratory physiological distress ${ }^{16,42,111,115}$. However, most doctors start treatment when the temperature is $>38.5^{\circ} \mathrm{C}^{116}$. Data that prove the superiority of one modality of antipyretic therapy over another are not available for the septic patient ${ }^{117}$. Table 2 lists some criteria for the choice of antipyretic methods (pharmacological and non-pharmacological).

It is important to remark that antipyretic agents act at the hypothalamic temperature set-point, which suppresses the heat generating response and, therefore, to be effective they require the integrity of the thermoregulatory system. In contrast, surface cooling devices reduce body temperature but do not decrease heat production. Both present opposing mechanisms on vascular tone: the first one cause's vasodilation to improve heat loss, while body cooling produces vasoconstriction, which will produce a different hemodynamic repercussion in the septic patient ${ }^{16}$ and should be considered carefully.

At present, it is not possible to establish with certainty whether treating the fever in septic patients without neurological impairment is beneficial or risky for their vital prognosis ${ }^{117,118}$ (Fig. 5). However, the available evidence indicates that a temperature $>40^{\circ} \mathrm{C}$ must be treated in any case ${ }^{117}$. In support of the fever treatment, it is pointed out that the induction of systemic changes caused by it, such as the increase in oxygen and energy demand (the latter being especially hazardous in the septic patient with hemodynamic dysfunction), can be reduced by an antipyretic strategy ${ }^{16}$. Similarly, experimental animal models have shown that fever can worsen inflammatory lung damage ${ }^{119,120}$ and exacerbate the damage induced by mechanical ventilation ${ }^{121}$.

However, the treatment of fever can mask symptoms and signs for the early diagnosis of severe infection ${ }^{122,123}$ and delay the start of an appropriate antibiotic therapy, 


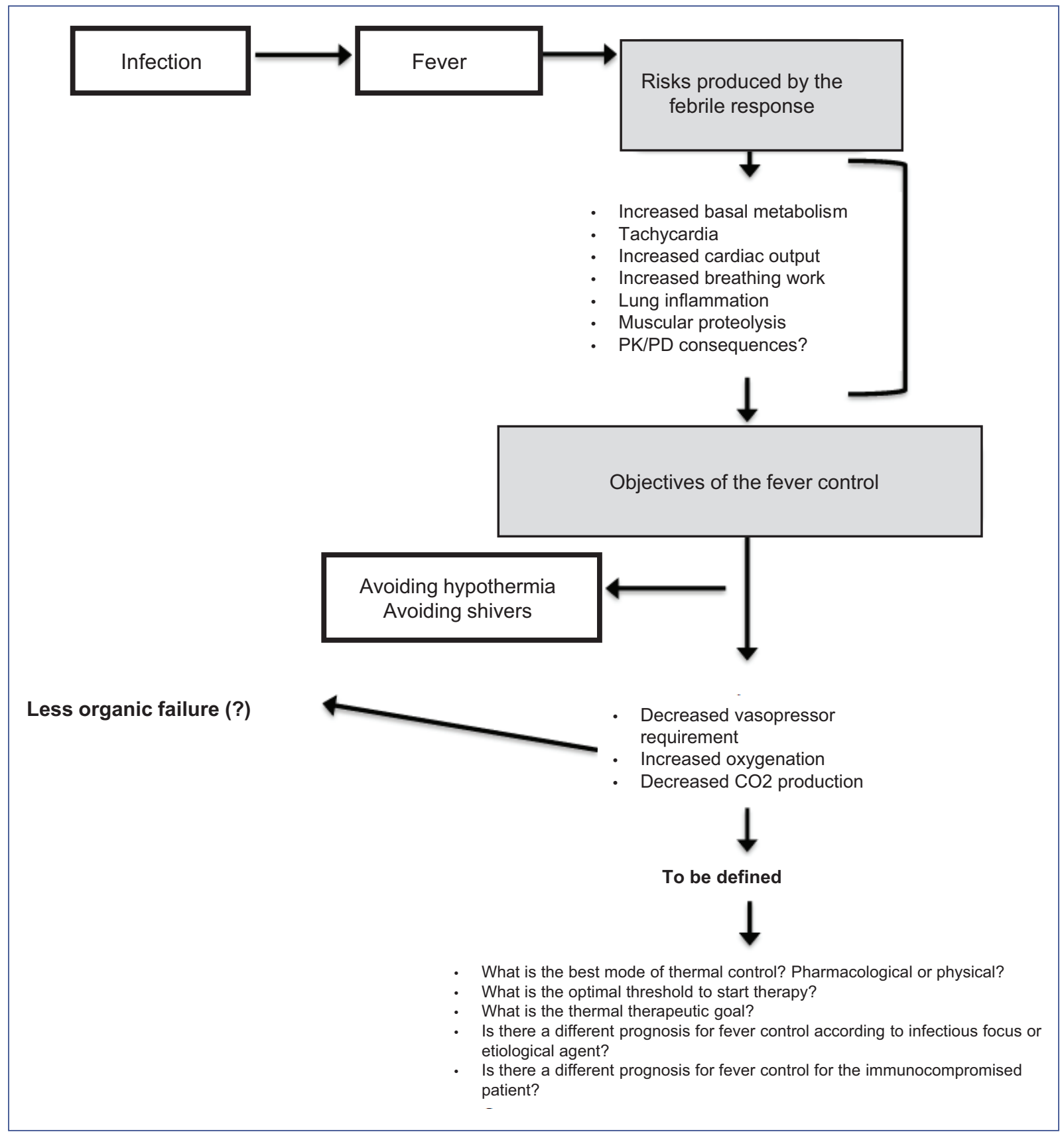

Figure 5. Potential (extra neurological) risks produced by fever in the septic patient and therapeutic goals of their control. PK/PD: pharmacokinetics/Pharmacodynamics; $\mathrm{CO}_{2}$ : carbon dioxide.

which is associated with higher mortality ${ }^{124}$. Furthermore, when deciding to treat fever indiscriminately, it should be considered that it improves cellular immune function ${ }^{125}$, determines the growth rate of some bacterial ${ }^{126}$ and vi$\mathrm{ral}^{127}$ pathogens, influences the magnitude of parasitemia $^{128}$ and optimizes the bactericidal action of antibiotic therapy ${ }^{129}$. Furthermore, clinical evidence indicates that the naturally hypothermic septic patient presents a worse vital prognosis compared to those who generate a febrile response ${ }^{130-132}$. Recently, a similar finding has been described for patients with acute respiratory distress syndro$\mathrm{me}^{133}$. Moreover, a multicenter observational study confirmed that the use of antipyretic agents, whether nonsteroidal anti-inflammatory drugs or acetaminophen, increases mortality in septic patients ${ }^{112}$. In the same line, the ongoing research, Fever and Antipyretic in Critically 
ill patients Evaluation (FACE II trial) ${ }^{134}$, will compare the safety and efficacy of two temperature control objectives $\left(<38^{\circ} \mathrm{C}\right.$ vs. $\left.<39.6^{\circ} \mathrm{C}\right)$ in patients' survival.

There are potential risks of antipyretic therapy concerning the temporal course of the disease, which is being evidenced in experimental conditions in vivo, as in the excessive release of TNF from immune cells (by the inhibition of negative feedback by $\left.P G E_{2}\right)^{135}$. At a clinical level, the use of acetaminophen has been related to the development of arterial hypotension ${ }^{136}$, with the presence of sepsis being a risk factor for presenting this effect ${ }^{137}$. Its use has also been associated with pyroglutamic acidosis in critical adult ${ }^{138}$ and pediatric ${ }^{139}$ patients. Recently, the role of this drug as an antioxidant in septic patients ${ }^{140}$ has been evaluated, and clinical trials on safety and efficacy in adult critical patients ${ }^{141,142}$ are under development (NCT02280239-NCT01869699).

There are currently few randomized studies evaluating the efficacy of antipyretic therapy in critically ill adult patients. Bernard et al. ${ }^{143}$ found no difference in mortality at 30 days with the use of ibuprofen for $48 \mathrm{~h}$ in septic patients with at least one organ dysfunction. Recently, Zhang et al. ${ }^{144}$ noted that there is no mortality reduction with the use of antipyretic therapy in septic patients. It has been demonstrated that the use of intravenous acetaminophen every $6 \mathrm{~h}$ versus placebo (HEAT study) in patients with or suspected infection and temperature $>38^{\circ} \mathrm{C}$ (20\% with septic shock) was not effective in decreasing the number of ICU freedays and did not present any beneficial effect on mortality at 28 and 90 days ${ }^{145-147}$. Two important meta-analyses concluded that the use of antipyretic therapy showed no benefit regarding mortality in ICU patients with infection and without neurological disea$\mathrm{se}^{148,149}$. Although the use of antipyretic drugs ${ }^{143,150,151}$ reduces the temperature in the critical patient ${ }^{152}$, there is no conclusive evidence on its effectiveness in reducing mortality ${ }^{153}$.

About the use of surface cooling to reach normothermia (TTM: $36.5-37^{\circ} \mathrm{C}$ ) in the adult patient with febrile septic shock and assisted ventilation, a French multicentric study proved that it was safe and useful in decreasing the vasopressor requirements and produce a better survival at 14 days. However, there was a higher incidence of secondary infections in the treated group, and there was no difference in mortality at discharge from the ICU or the hospital ${ }^{154}$. A post hoc analysis confirmed that the observed decrease in mortality was a direct effect of the reduction of body temperature and not by the heart rate reduction ${ }^{155}$. The use of external cooling measures hardly is tolerated by the conscious patient; recently, it was pointed out that its use can be risky in the septic patient ${ }^{144}$.

Regarding the use of therapeutic hypothermia, the results of the Danish study named The Cooling and Surviving Septic Shock Study ${ }^{156}$, which evaluates the effect of induced hypothermia $\left(32-34^{\circ} \mathrm{C}\right)$ for $24 \mathrm{~h}$ followed by thermal control $\left(36-38^{\circ} \mathrm{C}\right)$ for $48 \mathrm{~h}$ on the mortality of adult patients with septic shock, has not been reported.

In the future, the now inconsistent results in the use of antipyretic therapy in critical patients, the systematic reviews and the meta-analyses should establish whether fever in a specific population is a marker of disease severity or is an associated risk factor and whether its treatment could improve the vital prognosis.

\section{Conclusions}

Fever is an evolutionarily ancient and well-preserved, usually beneficial, response of the host to infection. However, the association between fever, its etiology, antipyretic treatment, and morbidity-mortality is particularly complex, and many questions are still present.

The continuous progress in knowledge about the pathophysiology of fever in the septic patient should lead to a better understanding of the reasons for employing a particular strategy of thermal control. Although there are currently no recommendations on a preferred method in the clinical practice, the physician does have precise, safe, and efficient options.

At present, there is no definitive evidence of a beneficial effect of the antipyretic therapy use in pediatric ICU septic patients. The evaluation of the biological response to a specific temperature control strategy will allow an individualized therapy, which should lead to more coherent management of the febrile patient and, eventually, an improvement in its prognosis.

\section{Ethical disclosures}

Protection of human and animal subjects. The authors declare that no experiments were performed on humans or animals for this study.

Confidentiality of data. The authors declare that they have followed the protocols of their work center on the publication of patient data.

Right to privacy and informed consent. The authors declare that no patient data appear in this article. 


\section{Conflicts of interest}

The authors declare no conflicts of interest.

\section{References}

1. Laupland KB, Shahpori R, Kirkpatrick AW, Ross T, Gregson DB Stelfox HT. Occurrence and outcome of fever in critically ill adults. Crit Care Med. 2008;36:1531-5.

2. Gordijn MS, Plötz FB, Kneyber MC. Fever during pediatric intensive care unit admission is independently associated with increased morbidity. J Intensive Care Med. 2009;24:317-22.

3. Kaul DR, Flanders SA, Beck JM, Saint S. Incidence, etiology, risk factors, and outcome of hospital-acquired fever. J Gen Intern Med. 2006;21:1184-7.

4. Toltzis $P$, Rosolowski $B$, Salvator A. Etiology of fever and opportunities for reduction of antibiotic use in a pediatric intensive care unit. Infect Control Hosp Epidemiol. 2001;22:499-504.

5. Hasday JD, Thompson C, Singh IS. Fever, immunity, and molecular adaptations. Compr Physiol. 2014;4:109-48.

6. Ryan AJ, Flanagan SW, Moseley PL, Gisolfi CV. Acute heat stress protects rats against endotoxin shock. J Appl Physiol. 1992;73:1517-22.

7. Kluger MJ, Kozak W, Conn CA, Leon LR, Soszynski D. The adaptive value of fever. Infect Dis Clin North Am. 1996;10:1-20.

8. Launey Y, Nesseler N, Mallédant Y, Seguin P. Clinical review: fever in septic ICU patients - friend or foe? Crit Care. 2011;15:222.

9. Melamud A, Suwezda A, Matamoros R, Ringuelet L. Antipyretics indication by pediatricians. Internet as a tool in data collections. Arch Argent Pediatr. 2008;106:404-8

10. Chiappini E, D’Elios S, Mazzantini R, Becherucci P, Pierattelli M, Galli L, et al. Adherence among Italian paediatricians to the Italian guidelines for the management of fever in children: a cross sectional survey. BMC Pediatrics. 2013;13:210.

11. Lava SA, Simonetti GD, Ramelli GP, Tschumi S, Bianchetti MG. Symptomatic management of fever by Swiss board-certified pediatricians: results from a cross-sectional, web-based survey. Clin Ther. 2012;34:250-6.

12. Ipp M, Jaffe D. Physicians' attitudes toward the diagnosis and management of fever in children 3 months to 2 years of age. Clin Pediatr (Phila). 1993;32:66-70

13. Moraga F, Horwitz B, Romero C. Fiebrefobia: conocimiento y actitud de los padres respecto de la fiebre. Rev Chil Pediatr. 2007;78:160-4.

14. May A, Bauchner H. Fever phobia: the pediatrician's contribution. Pediatrics. 1992:90:851-4.

15. Russell F, Shann F, Curtis N, Mulholland K. Evidence on the use of paracetamol in febrile children. Bull World Health Organ. 2003;81:367-72.

16. Gozzoli V, Treggiari MM, Kleger GR, Roux-Lombard P, Fathi M, Pichard C, et al. Randomized trial of the effect of antipyresis by metamizol, propacetamol or external cooling on metabolism, hemodynamics and inflammatory response. Intensive Care Med. 2004;30:401-7.

17. Bozzo J, Escolar G, Hernández MR, Galán AM, Ordinas A. Prohemorrhagic potential of dipyrone, ibuprofen, ketorolac, and aspirin: mechanisms associated with blood flow and erythrocyte deformability. J Cardiovasc Pharmacol. 2001;38:183-90.

18. Schaller S, Kaplan BS. Acute nonoliguric renal failure in children associated with nonsteroidal antiinflammatory agents. Pediatr Emerg Care. 1998:14:416-8

19. Schetz M, Dasta J, Goldstein S, Golper T. Drug-induced acute kidney injury. Curr Opin Crit Care. 2005;11:555-65.

20. Ng JL, Morgan DJ, Loh NK, Gan SK, Coleman PL, Ong GS, et al Life-threatening hypokalaemia associated with ibuprofen-induced renal tubular acidosis. Med J Aust. 2011;194:313-6.

21. Ulinski T, Guigonis V, Dunan O, Bensman A. Acute renal failure after treatment with non-steroidal anti-inflammatory drugs. Eur J Pediatr. 2004;163:148-50.

22. John CM, Shukla R, Jones CA. Using NSAID in volume depleted children can precipitate acute renal failure. Arch Dis Child. 2007;92:524-6.

23. Kearns GL, Leeder JS, Wasserman GS. Acetaminophen overdose with therapeutic intent. J Pediatr. 1998;132:5-8.

24. Penna A, Buchanan N. Paracetamol poisoning in children and hepatotoxicity. Br J Clin Pharmacol. 1991;32:143-9.

25. Doyle JF, Schortgen F. Should we treat pyrexia? And how do we do it? Crit Care. 2016;20:303.

26. Taccone FS, Saxena M, Schortgen F. What's new with fever control in the ICU. Intensive Care Med. 2014;40:1147-50.

27. Tzschentke B, Rumpf M. Embryonic development of endothermy. Respir Physiol Neurobiol. 2011;178:97-107.

28. Grigg GC, Beard LA, Augee ML. The evolution of endothermy and its diversity in mammals and birds. Physiol Biochem Zool. 2004;77:982-7.

29. Hasday JD, Singh IS. Fever and the heat shock response: distinct, partially overlapping processes. Cell Stress Chaperones. 2000;5:471-80.
30. Harden LM, Kent S, Pittman QJ, Roth J. Fever and sickness behavior: friend or foe? Brain Behav Immun. 2015;50:322-33.

31. Romanovsky AA. Thermoregulation: some concepts have changed. Functional architecture of the thermoregulatory system. Am J Physiol Regul Integr Comp Physiol. 2007;292:R37-46.

32. Brown PJ, Dove RA, Tuffnell CS, Ford RP. Oscillations of body temperature at night. Arch Dis Child. 1992;67:1255-8.

33. Council on Sports Medicine and Fitness and Council on School Health, Bergeron MF, Devore C, Rice SG; American Academy of Pediatrics. Policy statement - climatic heat stress and exercising children and adolescents. Pediatrics. 2011;128:e741-7.

34. Inbar O, Morris N, Epstein Y, Gass G. Comparison of thermoregulatory responses to exercise in dry heat among prepubertal boys, young adults, and older males. Exp Physiol. 2004;89:691-700.

35. Waldron, S, MacKinnon, R. Neonatal thermoregulation. Infant. 2007;3:101-4.

36. Simmers L. Diversified health occupations. Canada: Delmar; 1988. p. 150-1.

37. Eichenwald HF. Fever and antipyresis. Bull World Health Organ. 2003;81:372-4.

38. Inoue $Y$, Kuwahara T, Araki T. Maturation and aging-related changes in heat loss effector function. J Physiol Anthropol Appl Human Sci. 2004;23:289-94.

39. Mohawk JA, Green CB, Takahashi JS. Central and peripheral circadian clocks in mammals. Annu Rev Neurosci. 2012;35:445-62.

40. Gazendam JA, Van Dongen HP, Grant DA, Freedman NS, Zwaveling JH, Schwab RJ. Altered circadian rhythmicity in patients in the ICU. Chest. 2013;144:483-9.

41. Niven DJ, Gaudet JE, Laupland KB, Mrklas KJ, Roberts DJ, Stelfox HT. Accuracy of peripheral thermometers for estimating temperature: a systematic review and meta-analysis. Ann Intern Med. 2015;163:768-77.

42. Niven DJ, Laupland KB, Tabah A, Vesin A, Rello J, Koulenti D, et al. Diagnosis and management of temperature abnormality in ICUs: a EUROBACT investigators' survey. Crit Care. 2013;17:R289.

43. Glossary of terms for thermal physiology. $2^{\text {nd }}$ ed. Revised by The Commission for Thermal Physiology of the International Union of Physiological Sciences (IUPS Thermal Commission). Pflugers Arch. 1987;410:567-87.

44. Roth J, Blatteis CM. Mechanisms of fever production and lysis: lessons from experimental LPS fever. Compr Physiol. 2014;4:1563-604.

45. Mackowiak PA, Bartlett JG, Borden EC, Goldblum SE, Hasday JD, Munford RS, et al. Concepts of fever: recent advances and lingering dogma. Clin Infect Dis. 1997;25:119-38.

46. Satinoff E, McEwen GN Jr, Williams BA. Behavioral fever in newborn rabbits. Science. 1976;193:1139-40.

47. McCusker RH, Kelley KW. Immune-neural connections: how the immune system's response to infectious agents influences behaviour. J Exp Biol. 2013;216:84-98

48. El-Radhi A, Carroll J, Klein N, Abbas A. Fever. In: Sahib El-Radhi A, Carroll J, Klein N, editors. Clinical manual of fever in children. Berlin, Heidelberg: Springer-Verlag; 2009. p. 1-24.

49. Kluger MJ. Phylogeny of fever. Fed Proc. 1979;38:30-4.

50. Kluger M. The evolution of fever. In: Fever: its biology, evolution, and function. New Jersey: Kluger M. Princeton University Press; 1979. p. 106-27

51. Bernheim HA, Bodel PT, Askenase PW, Atkins E. Effects of fever on host defence mechanisms after infection in the lizard Dipsosaurus dorsalis. Br J Exp Pathol.1978;59:76-84

52. Bundey S, Raymond S, Dean P, Roberts SK, Dillon RJ, Charnley AK. Eicosanoid involvement in the regulation of behavioral fever in the desert locust, Schistocerca gregaria. Arch Insect Biochem Physiol. 2003;52:183-92.

53. Bernheim HA, Kluger MJ. Fever: effect of drug-induced antipyresis on survival. Science. 1976;193:237-9.

54. Reynolds WW. Fever and antipyresis in the bluegill sunfish, Lepomis macrochirus. Comp Biochem Physiol C. 1977;57:165-7.

55. Ruben J. The evolution of endothermy in mammals and birds: from physiology to fossils. Annu Rev Physiol.1995;57:69-95.

56. Bergman A, Casadevall $A$. Mammalian endothermy optimally restricts fungi and metabolic costs. MBio. 2010;1:e00212-310.

57. Quan N. In-depth conversation: spectrum and kinetics of neuroimmune afferent pathways. Brain Behav Immun. 2014:40:1-8.

58. Mogensen TH. Pathogen recognition and inflammatory signaling in innate immune defences. Clin Microbiol Rev. 2009;22:240-73.

59. Leon LR. Invited review: cytokine regulation of fever: studies using gene knockout mice. Appl Physiol. 2002;92:2648-55.

60. Blatteis $\mathrm{CM}$. The onset of fever: new insights into its mechanism. Prog Brain Res. 2007;162:3-14

61. Sehic E, Blatteis CM. Blockade of lipopolysaccharide-induced fever by subdiaphragmatic vagotomy in guinea pigs. Brian Res. 1996;726:160-6.

62. Luheshi GN. Cytokines and fever. Mechanisms and sites of action. Ann N Y Acad Sci. 1998;856:83-9.

63. Ivanov AI, Romanovsky AA. Prostaglandin E2 as a mediator of fever: synthesis and catabolism. Front Biosci. 2004;9:1977-93.

64. Vasilache AM, Qian H, Blomqvist A. Immune challenge by intraperitoneal administration of lipopolysaccharide directs gene expression in distinct blood-brain barrier cells toward enhanced prostaglandin $\mathrm{E}(2)$ signaling. Brain Behav Immun. 2015;48:31-41. 
65. Pettus BJ, Bielawski J, Porcelli AM, Reames DL, Johnson KR, Morrow J, et al. The sphingosine kinase $1 /$ sphingosine-1-phosphate pathway mediates COX-2 induction and PGE2 production in response to TNF-alpha. FASEB J. 2003;17:1411-21.

66. Matsumura K, Cao C, Ozaki M, Morii H, Nakadate K, Watanabe Y. Brain endothelial cells express cyclooxygenase-2 during lipopolysaccharide-induced fever: light and electron microscopic immunocytochemical studies. J Neurosci. 1998;18:6279-89.

67. Inoue W, Matsumura K, Yamagata K, Takemiya T, Shiraki T, Kobayashi S. Brain-specific endothelial induction of prostaglandin $\mathrm{E}(2)$ synthesis enzymes and its temporal relation to fever. Neurosci Res. 2002:44:51-61.

68. Yamagata K, Matsumura K, Inoue W, Shiraki T, Suzuki K, Yasuda S, et al. Coexpression of microsomal-type prostaglandin $E$ synthase with cyclooxygenase- 2 in brain endothelial cells of rats during endotoxin-induced fever. J Neurosci. 2001;21:2669-77.

69. Tachikawa M, Ozeki G, Higuchi T, Akanuma S, Tsuji K, Hosoya K. Role of the blood-cerebrospinal fluid barrier transporter as a cerebral clearance system for prostaglandin $\mathrm{E}(2)$ produced in the brain. $\mathrm{J}$ Neurochem. 2012;123:750-60.

70. Sánchez-Alavez M, Tabarean IV, Behrens MM, Bartfai T. Ceramide mediates the rapid phase of febrile response to IL-1 $\beta$. Proc Natl Acad Sci USA. 2006;103:2904-8.

71. Simmons DL, Wagner D, Westover K. Nonsteroidal anti-inflammatory drugs, acetaminophen, cyclooxygenase 2, and fever. Clin Infect Dis. 2000;31:S211-8.

72. Li S, Wang Y, Matsumura K, Ballou LR, Morham SG, Blatteis CM. The febrile response to lipopolysaccharide is blocked in cyclooxygenase-2(-/-), but not in cyclooxygenase-1(-/-) mice. Brain Res. 1999;825:86-94.

73. Schwartz JI, Chan CC, Mukhopadhyay S, McBride KJ, Jones TM, Adcock $\mathrm{S}$, et al. Cyclooxygenase-2 inhibition by rofecoxib reverses naturally occurring fever in humans. Clin Pharmacol Ther. 1999; 65:653-60.

74. Engström Ruud L, Wilhelms DB, Eskilsson A, Vasilache AM, Elander L, Engblom D, et al. Acetaminophen reduces lipopolysaccharide-induced fever by inhibiting cyclooxygenase-2. Neuropharmacology. 2013;71:124-9.

75. Arruda AP, Milanski M, Romanatto T, Solon C, Coope A, Alberici LC, et al. Hypothalamic actions of tumor necrosis factor alpha provide the thermogenic core for the wastage syndrome in cachexia. Endocrinology. 2010;151:683-94.

76. Nakamura K. Central circuitries for body temperature regulation and fever. Am J Physiol Regul Integr Comp Physiol. 2011;301:R1207-28.

77. Dünser MW, Hasibeder WR. Sympathetic overstimulation during critical illness: adverse effects of adrenergic stress. J Intensive Care Med. 2009;24:293-316.

78. Nalivaiko E. Tachycardia during fever: is it neural or humoral? Am J Physiol Regul Integr Comp Physiol. 2006;290:R1750.

79. Takayama K, Yuhki K, Ono K, Fujino T, Hara A, Hara A, et al. Thromboxane $\mathrm{A} 2$ and prostaglandin F2alpha mediate inflammatory tachycardia. Nat Med. 2005;11:562-6.

80. Davies P, Maconochie I. The relationship between body temperature, heart rate and respiratory rate in children. Emerg Med J. 2009;26:641-3.

81. Thompson M, Harnden A, Perera R, Mayon-White R, Smith L, McLeod D, et al. Deriving temperature and age appropriate heart rate centiles for children with acute infections. Arch Dis Child. 2009;94:361-5.

82. Hata JS, Shelsky CR, Hindman BJ, Smith TC, Simmons JS, Todd MM. A prospective, observational clinical trial of fever reduction to reduce systemic oxygen consumption in the setting of acute brain injury. Neurocrit Care. 2008;9:37-44.

83. Manthous CA, Hall JB, Olson D, Singh M, Chatila W, Pohlman A, et al. Effect of cooling on oxygen consumption in febrile critically ill patients. Am J Respir Crit Care Med. 1995;151:10-4.

84. Sakata Y, Morimoto A, Murakami N. Changes in plasma catecholamines during fever induced by bacterial endotoxin and interleukin-1 beta. Jpn J Physiol. 1994;44:693-703.

85. Poblete B, Romand JA, Pichard C, König P, Suter PM. Metabolic effects of i.v. propacetamol, metamizol or external cooling in critically ill febrile sedated patients. Br J Anaesth. 1997;78:123-7.

86. Young PJ, Saxena M. Fever management in intensive care patients with infections. Crit Care. 2014;18:206.

87. Malhotra V, Wong HR. Interactions between the heat shock response and the nuclear factor-kappa $B$ signaling pathway. Crit Care Med. 2002;30:S89-S95.

88. Schlesinger M. Heat shock proteins. J Biol Chem. 1990;265:12111-4.

89. Wheeler DS, Fisher LE Jr, Catravas JD, Jacobs BR, Carcillo JA, Wong HR. Extracellular hsp70 levels in children with septic shock. Pediatr Crit Care Med. 2005;6:308-11.

90. Kregel KC. Heat shock proteins: modifying factors in physiological stress responses and acquired thermotolerance. J Appl Physiol. 2002; 92:2177-86.

91. Gerner EW, Schneider MJ. Induced thermal resistance in HeLa cells. Lancet. 1975;256:500-2.

92. Kiang JG, Tsokos GC. Heat shock protein $70 \mathrm{kDa}$ : molecular biology, biochemistry, and physiology. Pharmacol Ther. 1998;80:183-201.
93. Pavlik A, Aneja IS, Lexa J, Al-Zoabi BA. Identification of cerebral neurons and glial cell types inducing heat shock protein Hsp70 following heat stress in the rat. Brain Res. 2003;973:179-89.

94. Tulapurkar ME, Almutairy EA, Shah NG, He JR, Puche AC, Shapiro P et al. Febrile-range hyperthermia modifies endothelial and neutrophilic functions to promote extravasation. Am J Respir Cell Mol Biol. 2012;46:807-14.

95. Djaldetti $\mathrm{M}$, Bessler $\mathrm{H}$. High temperature affects the phagocytic activity of human peripheral blood mononuclear cells. Scand J Cin Lab Invest. 2015;75:482-6.

96. Rainho CS, de Sá EA, Jabur Gaziri LC, Ostrensky Saridakis H, Felipe I. Modulation of lectinophagocytosis of Escherichia coli by variation of $\mathrm{pH}$ and temperature. FEMS Immunol Med Microbiol.1999;24:91-5.

97. Nagarsekar A, Greenberg RS, Shah NG, Singh IS, Hasday JD. Febrile-range hyperthermia accelerates caspase-dependent apoptosis in human neutrophils. J Immunol. 2008;181:2636-43.

98. Sarwari AR, Mackowiak PA. The pharmacologic consequences of fever. Infect Dis Clin North Am. 1996;10:21-32.

99. Beovic B, Mrhar A, Karba R, Zupancic T, Grabnar I, Belic A, et al. Influence of fever on the pharmacokinetics of ciprofloxacin. Int J Antimicrob Agents. 1999;11:81-5.

100. Kluger MJ, Ringler DH, Anver MR. Fever and survival. Science. $1975 ; 188: 166-8$

101. Vaughn LK, Bernheim HA, Kluger MJ. Fever in the lizard Dipsosaurus dorsalis. Nature. 1974;252:473-4.

102. Schmidt JR, Rasmussen AF Jr. The influence of environmental temperature on the course of experimental herpes simplex infection. $J$ Infect Dis. 1960;107:356-60.

103. Lwoff A. Factors influencing the evolution of viral diseases at the cellular level and in the organism. Bacteriol Rev. 1959;23:109-24.

104. Walker DL, Boring WD. Factors influencing host-virus interactions. III. Further studies on the alteration of Coxsackie virus infection in adult mice by environmental temperature. J Immunol. 1958;80:39-44.

105. Bell JF, Moore GJ. Effects of high ambient temperature on various stages of rabies virus infection in mice. Infect Immunol.1974;10:510-5.

106. Jiang Q, Cross AS, Singh IS, Chen TT, Viscardi RM, Hasday JD. Febrile core temperature is essential for optimal host defense in bacterial peritonitis. Infect Immun. 2000;68:1265-70.

107. Su F, Nguyen ND, Wang Z, Cai Y, Rogiers P, Vincent JL. Fever control in septic shock: beneficial or harmful? Shock. 2005;23:516-20.

108. Eyers S, Weatherall M, Shirtcliffe P, Perrin K, Beasley R. The effect on mortality of antipyretics in the treatment of influenza infection: systematic review and meta-analysis. J R Soc Med. 2010;103:403-11.

109. Jefferies S, Weatherall M, Young P, Eyers S, Beasley R. Systematic review and meta-analysis of the effects of antipyretic medications on mortality in Streptococcus pneumoniae infections. Postgrad Med. 2012;88:21-7.

110. Kluger MJ, Vaughn LK. Fever and survival in rabbits infected with Pasteurella multocida. J Physiol. 1978;282:243-51.

111. Selladurai S, Eastwood GM, Bailey M, Bellomo R. Paracetamol therapy for septic critically ill patients: a retrospective observational study. Crit Care Resusc. 2011;13:181-6.

112. Lee BH, Inui D, Suh GY, Kim JY, Kwon JY, Park J, et al. Association of body temperature and antipyretic treatments with mortality of critically ill patients with and without sepsis: multi-centered prospective observational study. Crit Care. 2012;16:R33.

113. Young PJ, Saxena M, Beasley R, Bellomo R. Early peak temperature and mortality in critically ill patients with or without infection. Intensive Care Med. 2012;38:437-44.

114. Weinkove R, Bailey M, Bellomo R, Saxena MK, Tam CS, Pilcher DV et al. Association between early peak temperature and mortality in neutropenic sepsis. Ann Hematol. 2015;94:857-64.

115. Niven DJ, Shahpori R, Stelfox HT, Laupland KB. Management of febrile critically ill adults: a retrospective assessment of regional practice. Ther Hypothermia Temp Manag. 2011;1:99-104.

116. Egi M, Morita K. Fever in non-neurological critically ill patients: a systematic review of observational studies. J Crit Care. 2012;27:428-33.

117. Theilen $H$, Ragaller $M$. Therapy of hyperthermia in sepsis and septic shock. Necessary or injurious? Anaesthesist. 2007;56:949-52.

118. Zhang Z. Antipyretic therapy in critically ill patients with established sepsis: a trial sequential analysis. PLoS One. 2015;10:e0117279.

119. Rice P, Martin E, He JR, Frank M, DeTolla L, Hester L, et al. Febrile-range hyperthermia augments neutrophil accumulation and enhances lung injury in experimental gram-negative bacterial pneumonia. J Immunol. 2005; $174: 3676-85$

120. Hasday JD, Garrison A, Singh IS, Standiford T, Ellis GS, Rao S, et al. Febrile- range hyperthermia augments pulmonary neutrophil recruitment and amplifies pulmonary oxygen toxicity. Am J Pathol. 2003:162:2005-17.

121. Suzuki S, Hotchkiss JR, Takahashi T, Olson D, Adams AB, Marini J. Effect of core body temperature on ventilator-induced lung injury. Crit Care Med. 2004;32:144-9.

122. O'Dempsey TJ, Laurence BE, McArdle TF, Todd JE, Lamont AC, Greenwood BM. The effect of temperature reduction on respiratory rate in febrile illnesses. Arch Dis Child. 1993;68:492-5. 


\section{A. Donoso, D. Arriagada: Fever and antipyretic therapy in the septic patient in the ICU}

123. Messika J, Sztrymf B, Bertrand F, Billard-Pomares T, Barnaud G, Branger $C$, et al. Risks of nonsteroidal antiinflammatory drugs in undiagnosed intensive care unit pneumococcal pneumonia: younger and more severely affected patients. J Crit Care. 2014;29:733-8.

124. Kumar A, Roberts D, Wood KE, Light B, Parrillo JE, Parrillo JE, et al. Duration of hypotension before initiation of effective antimicrobial therapy is the critical determinant of survival in human septic shock. Crit Care Med. 2006;34:1589-96.

125. Berman JD, Neva FA. Effect of temperature on multiplication of Leishmania amastigotes within human monocyte-derived macrophages in vitro. Am J Trop Med Hyg.1981;30:318-21.

126. Small PM, Täuber MG, Hackbarth CJ, Sande MA. Influence of body temperature on bacterial growth rates in experimental pneumococcal meningitis in rabbits. Infect Immun.1986;52:484-7.

127. Chu CM, Tian SF, Ren GF, Zhang YM, Zhang LX, Liu GQ. Occurrence of temperature-sensitive influenza A viruses in nature. J Virol.1982; 41:353-9.

128. Brandts $\mathrm{CH}$, Ndjavé $\mathrm{M}$, Graninger W, Kremsner PG. Effect of paracetamol on parasite clearance time in Plasmodium falciparum malaria. Lancet. 1997;350:704-9.

129. Mackowiak PA, Ruderman AE, Martin RM, Many WJ, Smith JW, Luby JP. Effects of physiologic variations in temperature on the rate of antibiotic-induced bacterial killing. Am J Clin Pathol.1981;76:57-62.

130. Peres Bota D, Lopes Ferreira F, Mélot C, Vincent JL. Body temperature alterations in the critically ill. Intensive Care Med. 2004:30:811-6.

131. Arons MM, Wheeler AP, Bernard GR, Christman BW, Russell JA, Schein R, et al. Effects of ibuprofen on the physiology and survival of hypothermic sepsis. Ibuprofen in Sepsis Study Group. Crit Care Med. 1999;27:699-707.

132. Kushimoto S, Gando S, Saitoh D, Mayumi T, Ogura H, Fujishima S, et al. The impact of body temperature abnormalities on the disease severity and outcome in patients with severe sepsis: an analysis from a multicenter, prospective survey of severe sepsis. Crit Care. 2013;17:R271.

133. Schell-Chaple HM, Puntillo KA, Matthay MA, Liu KD; National Heart, Lung, and Blood Institute Acute Respiratory Distress Syndrome Network. Body temperature and mortality in patients with acute respiratory distress syndrome. Am J Crit Care. 2015;24:15-23.

134. UMIN-CTR (Clinical Trials Registry). Japan; 2011. Available at: https:// upload.umin.ac.jp.

135. Roth J, Hübschle T, Pehl U, Ross G, Gerstberger R. Influence of systemic treatment with cyclooxygenase inhibitors on lipopolysaccharide-induced fever and circulating levels of cytokines and cortisol in guinea-pigs. Pflügers Arch. 2002;443:411-7.

136. de Maat MM, Tijssen TA, Brüggemann RJ, Ponssen HH. Paracetamo for intravenous use in medium- and intensive care patients: pharmacokinetics and tolerance. Eur J Clin Pharmacol. 2010;66:713-9.

137. Mrozek S, Constantin JM, Futier E, Zenut M, Ghardes G, Cayot-Constantin $S$, et al. Acetaminophene-inducedhypotension in intensive care unit: a prospective study. Ann Fr Anesth Reanim. 2009;28:448-53.

138. Dempsey GA, Lyall HJ, Corke CF, Scheinkestel CD. Pyroglutamic acidemia: a cause of high anion gap metabolic acidosis. Crit Care Med. 2000;28:1803-7.

139. Alados Arboledas FJ, de la Oliva Senovilla P, García Muñoz MJ, Alonso Melgar A, Ruza Tarrío F. Pyroglutamic acidemia associated with acetaminophen. An Pediatr (Barc). 2007;67:582-4.

140. Janz DR, Bastarache JA, Rice TW, Bernard GR, Warren MA Wickersham $\mathrm{N}$, et al. Randomized, placebo-controlled trial of acetaminophen for the reduction of oxidative injury in severe sepsis: the Aceta- minophen for the Reduction of Oxidative Injury in Severe Sepsis trial. Crit Care Med. 2015;43:534-41.

141. Safety and Efficacy of Acetaminophen in the Intensive Care Unit. NCT02280239. Available at: https://clinicaltrials.gov

142. Effects of intravenous acetaminophen on body temperature and hemodynamic responses in febrile critically ill adults. Available at: https://clinicaltrials.gov

143. Bernard GR, Wheeler AP, Russell JA, Schein R, Summer WR, Steinberg KP, et al. The effects of ibuprofen on the physiology and survival of patients with sepsis. The Ibuprofen in Sepsis Study Group. N Engl J Med. 1997;336:912-8.

144. Zhang Z, Chen L, Ni H. Antipyretic therapy in critically ill patients with sepsis: an interaction with body temperature. PLoS One. 2015;10:e0121919.

145. Young P, Saxena M, Bellomo R, Freebairn R, Hammond N, van Haren F, et al. Acetaminophen for fever in critically ill patients with suspected infection. N Engl J Med. 2015;373:2215-24.

146. Young PJ, Saxena MK, Bellomo R, Freebairn RC, Hammond NE, van Haren FM, et al. The HEAT trial: a protocol for a multicentre randomised placebo-controlled trial of IV paracetamol in ICU patients with fever and infection. Crit Care Resusc. 2012;14:290-6.

147. Young PJ, Weatherall M, Saxena MK, Bellomo R, Freebairn RC, Hammond NE, et al. Statistical analysis plan for the HEAT trial: a multicentre randomized placebo-controlled trial of intravenous paracetamol in intensive care unit patients with fever and infection. Crit Care Resusc. 2013;15:279-86

148. Niven DJ, Stelfox HT, Laupland KB. Antipyretic therapy in febrile criticaIly ill adults: a systematic review and meta-analysis. J Crit Care. 2013;28:303-10

149. Jefferies S, Weatherall M, Young P, Eyers S, Perrin KG, Beasley CR. The effect of antipyretic medications on mortality in critically ill patients with infection: a systematic review and meta-analysis. Crit Care Resus. 2011;13:125-31.

150. Haupt MT, Jastremski MS, Clemmer TP, Metz CA, Goris GB. Effect of ibuprofen in patients with severe sepsis: a randomized, double-blind, multicenter study. The Ibuprofen Study Group. Crit Care Med. 1991; 19:1339-47.

151. Vera P, Zapata L, Gich I, Mancebo J, Betbesé AJ. Hemodynamic and antipyretic effects of paracetamol, metamizol and dexketoprofen in critical patients. Med Intensiva. 2012;36:619-25.

152. Niven DJ, Stelfox HT, Léger C, Kubes P, Laupland KB. Assessment of the safety and feasibility of administering antipyretic therapy in critically ill adults: a pilot randomized clinical trial. J Crit Care. 2013:28:296-302.

153. Suzuki S, Eastwood GM, Bailey M, Gattas D, Kruger P, Saxena M, et al. Paracetamol therapy and outcome of critically ill patients: a multicenter retrospective observational study. Crit Care. 2015;19:162.

154. Schortgen F, Clabault K, Katsahian S, Devaquet J, Mercat A, Deye N, et al. Fever control using external cooling in septic shock: a randomized controlled trial. Am J Respir Crit Care Med. 2012;185:1088-95.

155. Schortgen F, Charles-Nelson A, Bouadma L, Bizouard G, Brochard L, Katsahian S. Respective impact of lowering body temperature and heart rate on mortality in septic shock: mediation analysis of a randomized trial. Intensive Care Med. 2015;41:1800-8.

156. Cooling And Surviving Septic Shock Study. Available at: https://clinicaltrials.gov

157. Walter EJ, Hanna-Jumma S, Carraretto M, Forni L. The pathophysiological basis and consequences of fever. Crit Care. 2016;20:200. 